\title{
The Existence of Decision Norms of the Constitutional Court as a Source of Legislative and Executive Laws
}

\author{
Adhitya Widya Kartika \\ UPN Veteran Jawa Timur, Indonesia \\ adhityawidyakartika@ymail.com
}

\begin{abstract}
Norms are behavioral guidelines in the Indonesian legal state. Norms continue to exist in the legislation and juridical consequences of constitutional court decisions, and in particular, that of the Constitutional Court. Legal norms have principles that are applied to a wider hierarchy of legal norms and the production of legislation. In essence, the Constitutional Court's rulings have consequences on the actions of the government and therefore the action of governance. Including decision norms in the Constitutional Court's ruling has juridical consequences for the hierarchy of regulations and state legal actions in carrying out the function of government. This article aims to find out how to apply decision norms if there an identical or related decision exists within a different judicial institution. In government institutions bound by the Constitutional Court's decisions, application of decision norms resulted in chaos for the application and enforcement of the law. The implementing agency is faced with the same legal product, namely a verdict in another judicial institution. This causes no legal certainty. Rather than a solution or outcome, implementing agencies are faced with an identical legal response yet no legal certainty. The absence of legal certainty has consequences for government institutions that are bound by the Constitutional Court's decision. By utilizing a hierarchy of legal norms, the issue of rigidity and uncertainty caused by decision norms can be resolved. Likewise, in the legislature, the Constitutional Court's decision is the source of making legal norms. As the Constitutional Court's decision is the source of legal norm production in the legislature, espousing a hierarchy of legal norms will enable laws and regulations that are formed to reflect justice, certainty and benefit.
\end{abstract}

KEYWORDS: Court Decision, Legal Norms, Government.

Copyright $\odot 2019$ by Author(s)

This work is licensed under a Creative Commons Attribution-ShareAlike 4.0 International License. All writings published in this journal are personal views of the authors and do not represent the views of this journal and the author's affiliated institutions.

\section{HOW TO CITE:}

Kartika, Adhitya Widya. "The Existence of Decision Norms of the Constitutional Court as a Source of Legislative and Executive Laws" (2019) 6:2 Lentera Hukum 309-320.

Submitted: April 26, 2019 Revised: May 13, 2019 Accepted: May 31, 2019 


\section{INTRODUCTION}

As a democratic country, Indonesia has legislators who represent the interests of the government, people's aspirations, and regional needs. The legislature is an embodiment of the separation of powers in Trias Politica which requires checks and balances to ensure equality and to prevent abuse of power. One form of checks and balances is the existence of law testing faculties, especially with respect to the constitution, authorized to the Constitutional Court. K.C. Wheare defined the constitution as a whole system of government from a country in the form of a set of regulations that shape and determine regulations on the government. 'James Bryce defines a constitution as a frame of political society, organized through and by law, that is to say on which law has established permanent institutions with recognized functions and definite rights. ${ }^{2}$ The constitution has a special function and as a manifestation of the highest law (supremacy of law), that must be obeyed not only by the people but also by the government and authorities. ${ }^{3}$ The most effective way of limitation is to divide power. ${ }^{4}$ The test by the Constitutional Court has juridical consequences for the doctrine of the hierarchy of laws and regulations in the Republic of Indonesia Law No. 12 of 2011 concerning the Establishment of Legislation (UUP3). The Constitutional Court's decision to influence the existence of norms formed by the legislature furthermore has juridical consequences in its behavior and usability in government and society. Likewise, juridical consequences arise when a Constitutional Court decision is conflicts with other institutional court decisions, such as the Decision of the Administrative Court (PTUN) and the Decision of the Supreme Court (MA). The realization of legal harmonization (legal norms) is related to the objectives of legal norms: legal certainty, legal justice, and expediency. Juridical consequences are not only related to decisions between judicial institutions but also to the consequences of norms of conduct in the norm hierarchy. Principles in the normalization hierarchy not only have consequences on the normalization hierarchy but also have consequences on decisions related to legal norms.

The discussion on this issue is carried out by normative juridical analysis of legal theory, laws, and regulations. This discussion first needs to explore how norms are used as a source of other legal norms, including those arising from Constitutional Court decisions which became a source of government and administering government functions. Second, this paper will explore legal analysis regarding norm formation in Constitutional Court decisions, because it is important to know that at first, the Constitutional Court had a negative legislature function, yet later on developed into a positive legislature, such that it affected the actions of the government in the formation of legal products. Third, this paper will examine how the existence of norms in the

\footnotetext{
KC Wheare, Modern Constitution, Second Edition, Oxford, 1996 at 1.

CF Stong, Modern Political Constitutions, Sidgwick and Jackson Limited, London, 1966 at 20.

Miriam Budiardjo, Dasar-Dasar Ilmu Politik, Edisi Revisi, Gramedia Pustaka Utama, Jakarta, 2013 at 171.

4 Dahlan Thaib, dkk, Teori dan Hukum Konstitusi, RajaGrafindo Persada, Jakarta, 2011 at 19
} 
Constitutional Court's decision on the development of Indonesian state administration and how this decision is properly implemented.

The discussion of this legal issue has the goal of first knowing the norms which are then used in the development of other legal norms, including here Constitutional Court decisions which became a source of government administration. Second is to know the process by which norms are formed in Constitutional Court decisions. Finally, this paper aims to know the existence of norms in the Constitutional Court's decision on the development of Indonesian state administration, particularly with regard to the process and applicability of implementation in government function. The discussion is limited to the juridical consequences of legal norms and government legal actions related to decisions issued by the Constitutional Court.

\section{NORMS AND THE SOURCE OF LEGAL NORMS}

Indonesia has norms that contain das sollen and continue to impact people's lives (norms of trust, norms of decency, norms of politeness, and legal norms). Hans Kelsen argues that norms are characterized by levels, and Nawiasky believes that each level is a group. Kelsen and Nawiasky's organization concepts can be applied to legal norms in Indonesia; however, in general, the concept of norms at large-such as norms of trust, politeness, immorality and legal norms_cannot be hierarchical because, excluding legal norms, norms live side-by-side in society, sharing a position with one another. Legal norms are stronger because they have the power of the force. If other norms were organized into a hierarchical system, the distinction between norms will be unclear because norms will continue to live in society and could vary from one region to another. Registered legal norms are those codified in law (as in Article 7 paragraph (1) UUP3) which are regulatory (regeling), while deciding (beschiking) norms are hierarchical but concrete, an attribute not generally applied to regeling norms.

Stufentheorie explains the hierarchy of laws and regulations, for example, Kelsen's gurndnorm or Nawiasky's staatfundamentalnorm in the Pancasila and staatgrundgesetz in the Constitution (UUD 1945), formall gesetz or formal law, verordnung, and autonome sutzung. The hierarchy of laws and regulations according to Article 7 paragraph (1) UUP3 consists of (listed sequentially from above) the 1945 Constitution, Decree of the People's Consultative Assembly (TAP MPR), Laws (Undang-Undang), the Government Regulations in lieu of law (Peraturan Pemerintah Pengganti Undang-Undang), Government Regulations (Peraturan Pemerintah), Presidential Regulations (Peraturan Presiden), Provincial Regulations and Regency/City Regulation (Peraturan Daerah Provinsi/Kabupaten).

Forced power and forced tools to create legal norms stronger than other norms and punish those who violate the norm. The making of legal norms is legalistic/legitimate if the author has authority. The nature of legal norms applies continuously act as a doctrine in the life of the state with juridical consequences for the 
rule of law in Indonesia. Doctrine or theory on rule of law emphasizes supremacy within society and more importantly that the state is bound by law. ${ }^{5}$ That is, everything that the government does, including the production of law, must be in accordance with extant laws and regulations because of the existence of a legal state. Legal norms, viewed from the way they are made and their enactment, can be said to be dynamic. Upon production, the law must be rooted in higher norms, which in turn should permeate the entire hierarchy of law within a state, such that even the highest law and norms themselves are rooted in higher norms. From this basic principle, we can see the form of hierarchy in legal norms. The norm hierarchy is also subject to principles such as lex specialis derogat lex generalis and lex superior derogat legi inferior. ${ }^{6}$ In addition, legal norms must follow the development of society so that law is not left behind. When making a legal norm, both state and society must have targeted aspirations. In the production of law, it is important to note which material and formal legal sources utilized. The material legal sources in the case of rechtsborn in historische zin refer to past law or the law that has been enforced before, including both doctrine and judicial verdict. Legal sources are very important in legal production, as they promote and maintain harmonization of laws with the effect of minimizing imbalance between legal norms. Legal source materials-as they shape legal norms, especially when ratified-have significant impact serving as a guideline for a government function.

Regulations can sometimes experience changes, including the elimination of norms or shifting of legal norms. Changes and revocation of norms affect the behavior and usability of a legal norm. The revocation can be accomplished if a certain legal norm does not match the development of society. Revocation is different from changes in legal norms. Revocation of legal norms can be carried out an equivalent or higher level of non-legal norms so that they do not apply entirely. This differs from changes in a legal norm that can be carried out in part or in relation to all norms involved in a legal product. In addition to revocation and change, legal norms can experience changes in meaning by way of shifting norm meaning. Such a shift in norm meaning is considered the horizontal dynamic of legal norms, made possible by the withdrawal of a norm analogy. Legal norms in a legal product remain the same, yet a shift in analogy can cause the widening or narrowing of a norm in scope.

The shift of legal norms can occur during the legislative drafting or after legislation is passed. This can occur after the legislative drafting due to the existence of a material test at an institution, for example, the Constitutional Court's Decision No. 30 / PUUXVI/2018 dated July 23, 2018. In addition, the Constitutional Court has been the only interpreter of the constitution written into the constitution itself. The concept of hierarchy in which norms must be based on both basic and higher norms is one manifestation of legal harmonization efforts. Harmonization of the law is important so

I Dewa Gege Palguna, Pengaduan Konstitusional (Constitutional Complaint), Upaya Hukum terhadap Pelanggaran Hak-Hak Konstitusional Warga Negara, Sinar Grafika, Jakarta, 2013 at 26.

6 King Faisal Sulaiman, Teori Peraturan Perundang-undangan dan Aspek Pengujiannya, Thafa Media, Yogyakarta, 2017 at 109. 
that there is legal order (i.e., a match between one norm and another), and as a result legal certainty and minimization of multiple interpretations of a legal norm.

The legal certainty of expediency and justice influences the guarantee of a legal norm's behavior and usability. If it's not harmonious, legal norms may indeed be both formally legitimate and imposed but at the practical level will conflict with other legal norms. The legal norm that has no power of conduct has no utility, indeed a legal norm that is not changed or is not even revoked, the legal norms still remain as norms without agency or use (power). Therefore, legal harmonization is important so that there is no conflict in the construction of the whole norm system so that there is a need for control.

\section{NORM CONSTRUCTION ON THE DECISIONS OF THE CONSTITUTIONAL COURT}

A norm control mechanism can be applied to legal norms. This control is intended to prevent the government from operating through authoritarianism. ${ }^{7}$ The legal norms that can be tested are regeling, beschikking, and judgment (vonnis). ${ }^{8}$ The Constitutional Court has the authority to test regeling at the level of law against the 1945 Constitution. The definition of constitution, in general, is a legal system and basic principles that shape the nature, function, and limitations of the government or other institutions. ${ }^{9}$ The authority of the Constitutional Court has been regulated in the 1945 Constitution after amendments to Article 24C Paragraph (1), which states that the Constitutional Court has the authority to adjudicate at the first and final level. Decisions produced by the Constitutional Court are final. Laica Marzuki, professor of law and former constitutional judge, explains that when a constitutional court acts as a negative legislator, the parliament who formed the law is considered a positive legislator. ${ }^{10}$

The function of the Constitutional Court as a negative legislator can be emphasized by explaining that the Constitutional Court only confirms or decides whether a regulation or law conflicts with the Constitution (i.e., authority to interpret). Initially, the role of the Constitutional Court in examining laws did not include regulation formation. At a practical level, the Constitutional Court's authority operates as both negative and positive legislator. In fact, the Constitutional Court's decision on the testing of laws against the constitution contained conditionally constitutional and conditionally unconstitutional terms. Conditionally constitutional is seen in Decision No. 10/PUU-VI/2018

Zainal Arifn Hoesein, Judicial Review di Mahkamah Agung: Tiga Dekade Pengujian Peraturan Perundang-undangan, Raja Grafindo Persada, Jakarta, 2009 at 58.

8 Marjanne Termorshuizen, Kamus hukum Belanda-Indonesia, Penerbit Djambatan, 1998 at 506.

9 J. Scott Harr and Karen M. Hess, Constitutional Law and The Criminal Justice System, Second Edition, Thomson Learning, Wadsworth, 2002 at 4.

10 Laica Marzuki, Membangun Undang-Undang yang Ideal, Jurnal Legislasi Indonesia, Vol. 4, No. 2,Juni, Direktorat Jenderal Peraturan Perundang-Undangan Departemen Hukum dan HAM RI, Jakarta, 2007 at 6. 
concerning the testing of Law No. 10 of 2008 on General Elections of Members of the People's Representative Council and Regional Representative Council.

The point is that a law that is tested by the Constitutional Court can be identified by the Constitutional Court as contradictory or non-conflicting if its implementation is not in accordance with the Constitutional Court's specific interpretation of the law in the Constitution. The Constitutional Court's decision also issued a ruling regarding the existence of new norms, for example, Constitutional Court Decision No. 102/PUU-VII/2009 relating to the Citizen Card and Passport as the identity of the 2009 General Election. The decision shows the shifting function of the Constitutional Court negative legislators and positive legislators. The Constitutional Court's decision impacted its implementation.

The Constitutional Court's decision has a final nature in accordance with Article 24C paragraph (1) of the 1945 Constitution. This provision was followed by legislation below, such as Article 9 paragraph (1) UUP3. If the law is suspected to contradict the constitution, a test is conducted by the Constitutional Court other than that specified in Article 10 paragraph (1) of Law No. 24 of 2003 on the Constitutional Court. The Court has the authority to try the first and last levels and make final decisions, meaning there are no legal remedies before or after the Constitutional Court's decision. As a result, there is no other effort and the decision of the Court can be considered a last resort. The provisions also apply to test the law against the 1945 Constitution, which means that in any questions of law's constitutionality, the Court is the final decider. This provision is supported by Article 10 paragraph (1) of the Constitutional Court Law, stating that the Constitutional Court's decision is final, directly obtains permanent legal force once it is pronounced, and no legal remedy can be taken in response to the decision.

Constitutional Court Law changes several articles, which can be found in Law No. 8 of 2011 concerning Amendments to Law No. 24 of 2003 on the Constitutional Court. In Law No. 8 of 2011, the explanation of Article 10 is amended so that it reads as follows: paragraph (1) that the Constitutional Court decision is final, meaning the Constitutional Court's decision directly obtains permanent legal force and no legal remedy can be taken. The final nature of Constitutional Court decisions are not only final but also binding. However, this change was tested by the Constitutional Court in Decision No. 49/PUU-IX/201l because it was considered inconsistent with fundamental legislation formation. Decision No. 49 granted the application of Article 10, such that Article 10 of Law No. 8 of 2011 on the Amendment of Law No. 24 of 2003 on the Constitutional Court was declared void of binding legal force because it was not in accordance with the draft regulation on legislation. If this is the case, then the applicable law for Constitutional Court decisions and decision force is Article 10 paragraph (1) of Law No. 24 of 2003.

Article 57 paragraph (1) of Law No. 24 of 2003 on the Constitutional Court was amended by Law No. 8 of 2011 on the Amendment of Law No. 24 of 2003 ruled that content material (verses, articles, or parts of the law) which are contrary to the 1945 
Constitution do not have binding legal force. Therefore, if a norm is tested at the Constitutional Court and declared unconstitutional, it automatically means that the norm is not valid. The decision description explains that (1) law which is against the constitution can be tested in the Constitutional Court, (2) the Constitutional Court's decision is final, (3) if Constitutional Court decisions state that a norm contradicts the constitution, then the norm does not have binding legal force. This principle is, of course, binding in Constitutional Court verdict No. 30/PUU-XVI/2018, decided on 23 July 2018.

Constitutional Court's Decision No. 30/PUU-XVI/2018, concerned with Article 182 letter 1 of Law No. 7 of 2017 on General Elections (Election Law) and the 'other work' division, stipulates the conditions for prospective members of the Regional Representative Council (DPD) to not be administrators (functionaries) of political parties since the 2019 General Election and subsequent general elections. The Constitutional Court's ruling did not specify whether the relevant norms did or did not contradict the Constitution, yet within the Constitutional Court's decision was a shift in analogy. Initially, norms had 'other jobs' without being given more concrete statements, but after the Constitutional Court's decision came the board of political parties, which used different diction in reference to the same norm. The interpretation of norms by Constitutional Court Decisions have juridical consequences, barring political party administrators from participating in elections as general DPD members. Considering that the Constitutional Court's decision is final, the General Election Commission (KPU), in following the decision, issued KPU Regulation No. 26 of 2018 which contained the terms of resignation for prospective DPD members from the management of political parties. Das sollen can be seen on the Constitutional Court of the Republic of Indonesia No. 93/PUU-XV/2017 dated March 20, 2018. ${ }^{11}$ This decision explained Supreme Court reasoning for postponing an investigation request regarding the right of judicial review (No. 65 P / HUM / 2018) while in fact, the Supreme Court's Decision No. 65P/HUM/2018 was issued and the Jakarta PTUN decision No. 242/G/SPPU/2018/ PTUN.JKT. The provisions of Article 55 of the Constitutional Court Law also determine the termination of cases. This provision aims to ensure that in deciding the testing of laws and regulations, under the law being handled, the Supreme Court does not use norms that may conflict with the 1945 Constitution. ${ }^{12}$ In essence, the two decisions contradict the Constitutional Court decision, issued at a later date, causing confusion against other institutions wishing to implement the Constitutional Court Decision.

11 Constitutional Court Decision No. 93/PUU-XV/2017 that the phrase 'stopped' in Article 55 of Law No. 24 of 2003 on the Constitutional Court was amended by the Law of the Republic of Indonesia Number 24 of 2003 on the Constitutional Court contrary to the 1945 Constitution and has no power the law insofar as it is not interpreted The examination of the laws and regulations under the law that are proceeding with the Supreme Court has been postponed if the law on which the regulation is based is in the process of testing the Constitutional Court up to the Constitutional Court decision.

12 I Dewa Gede. Palguna, Mahkamah Konstitusi Dasar Pemikiran, Kewenangan, dan Perbandingan Dasar Negara Lain, Konstitusi Press, Jakarta, 2018 at 105. 
In Constitutional Court's Decision No. 79/PUU-XV/2017, dated November 28, 2017, the power of the decision applies in its essence. First, deciding a decision is one of the authorities of the Constitutional Court which has been regulated in Article 10 paragraph (1) of Law No. 24 of 2003 concerning the Constitutional Court amended by Law No. 8 of 201l. The decision handed down by the Constitutional Court is final, binding, and declarative, requiring no special apparatus for implementation. Second, the Court's decision can and should test the laws against the 1945 Constitution, since its object is a law that applies generally to have juridical consequences. It must be understood that law is general and abstract, applying to all people, as opposed to laws with concrete meaning that apply to specific people or entities (beschiking).

\section{THE EXISTENCE OF NORMS IN DECISIONS OF THE CONSTITUTIONAL COURT}

The existence of norms in Constitutional Court decisions can be viewed from several perspectives. First, relating to the roles and functions of the constitutional court. the Constitutional Court has authority granted by the Constitution to test law against the Constitution with the aim of determining its constitutionality. The verdict is final, allowing for no other efforts that bring juridical consequences such that the Constitutional Court's decision can be directly implemented. The Constitutional Court's authority to test a law against the Constitution means that the court has the authority to interpret both the Constitution and the laws tested against it. Authority refers to the Court's role as sole interpreter. Although other state institutions are not prohibited from providing interpretations of the Constitution, in a country that has a Constitutional Court, only the interpretation of the Constitutional Court has legally binding power. ${ }^{13}$ Therefore, the Constitutional Court decides the meaning and implications of the Constitution, resulting in the testing of the law's meaning. Law has general material content, so it applies generally, having juridical consequences on behavior and activities in government and society at large. The meaning of law applies to all lines of legal activity related to norms.

Second, norms in Constitutional Court decisions can be seen from the perspective of a legal norm hierarchy. The highest norm theory is staatsfundamentalnorm or Pancasila. Pancasila as the principle of various legislative norms in Indonesia, ensuring that all laws and regulations should reflect the principles of staatsfundamentalnorm. In paragraph IV of the Preamble of the 1945 Constitution, there is a basis for the people's sovereignty. The principles of Pancasila are imbedded in state sovereignty's implementation, as stated in the opening of the 1945 Constitution. The establishment of statutory regulation is one form of state or government activity; therefore the drafting of laws and regulations should reflect the Pancasila principle as listed in Constitution. The norm

13 Jimly Asshiddiqie, Pokok-pokok Hukum Tata Negara Indonesia Pasca Reformasi, Bhuana Ilmu Populer, Jakarta, 2007 at 605. 
hierarchy level under staatfundamentalnorm is staatgrundgesetz. The Constitution in the hierarchy of laws and regulations in Article 7 paragraph (1) UUP3 is a statutory regulation that has the uppermost hierarchical position. Article 7 paragraph (2) UUP3 states that the legal force of statutory regulations is in accordance with the hierarchy so that it increasingly emphasizes the height and status of constitutional power. The higher force of constitutional enactment implies that constitutional norms underlie other existing norms that are increasingly close to the harmonization of law because thus the norm will not come out of the frame that has been determined by the rules underlying the making of statutory regulation. Legal harmonization requires all laws and regulations to be aligned so that there is no conflict between laws and regulations resulting in the absence of legal certainty.

Constitutional Court's decisions have the characteristics in kracht van gewijsde and erga omnes which mean the decision can be implemented. Foundational legal norms are binding because of the general legal source material from which they are composed. The existence of the norms in Constitutional Court decisions impacts the formation of legislation below it and has implications for other state agencies that are bound to regulation. The Constitutional Court's ruling on a certain norm must be carried out considering that the Constitution is the highest regulation in norm and legal hierarchies. Implementing a constitutional ruling is tantamount to implementing the constitution itself. If there are other legal products that conflict with the ruling, for example, those related to the Supreme Court's decision or the Administrative Court decision, in compliance with the Constitutional Court Decision No. 93/PUU-XV/2017 there should be a delay, even if a decision is ultimately made in favor of constitutionality. In other words, testing a legal product through constitutional norms is the comparable to interpreting the constitution. As a result, implementation of the constitutional ruling is not a necessary concern. The roots of applied Court decisions, hierarchically, bring about a harmonious system of legislation. Constitutional Court's decisions will serve as basis for the legislature to make laws. For example, a law is declared unconstitutional so that all derivative regulations relating to the norms of that law are unconstitutional. Likewise, when conditionally constitutional or unconstitutional rulings occur, they will impact subsequent laws or legal products that sit below them on the norm hierarchy. This also affects other legal products produced by legislation. Therefore, the existence of norms in Constitutional Court decisions must impact and bind all lines of legal products under the Constitution and legal products under the law at large.

The explanation above can be concluded that the existence of a norm in the Constitutional Court decision continues to be carried out at the level of the legal product below. The nature of the binding power of statutory regulation is also influenced by a decision made by testing the legal product. Likewise, the opposite of the binding power possessed by a norm influences the binding power of decisions on testing a related norm. This has implications for the behavior of the government, including the legislature in the creation of law. Constitutional Court decisions become 
the source of legal and non-legal norms. Those judged unconstitutional automatically cannot be used as the basis for norm-making. This also applies to executives in carrying out their government activities and in making policies, especially with respect to the formation of legal norms. The Court does not have the tools to guarantee that a decision is truly enforced; therefore, its existence depends upon actions carried out by the legislature and the executive.

\section{CONCLUSION}

The Constitutional Court's decision is one of the legal products which is the result of the interpretation of the 1945 Constitution against the law. The Constitutional Court's decision is a final decision which should be applied by the institution that is bound by the decision. Some important things are known in the results of the discussion. First, the understanding of norms as legal material or sources is derived from the decisions of the Constitutional Court. The Constitutional Court's decision which is a regeling interpretation was used as a legal source for the DPR as a legislator to form legal norms (UU) and as a guideline for the KPU (executive part) in carrying out its government functions, including issuing beschiking legal products. Second, norm formation in Constitutional Court decisions is the result of the Court's interpretation of the 1945 Constitution. Interpretation can take the form of unconstitutional, constitutional, conditionally constitutional, or conditionally unconstitutional decisions. The norms embedded in a Court decision can shift horizontally, altering a norm analogy by either broadening or narrowing. Such a shift can be viewed not just change, but even as the formation of new norms. Changes occur relative to the Constitution and are unconstitutional. Formation of norms can occur when there is a shift in analogy, even when the Constitutional Court rules upon the terms of its decision.

Finally, the existence of norms in Constitutional Court decisions on the development of Indonesian state administration occurred when the Constitutional Court's decision was applied to matters that were targeted at the decision. For example, the Application of Constitutional Court Decision No. 30/PUU-XVI/2018 which was then implemented by the KPU and became a reference for the formation of norms by the House of Representatives. The implementation of the Constitutional Court Decision by the KPU when it ruled out the Supreme Court and Administrative Court decisions that were considered contrary to the Constitutional Court decision was not an issue. Basically, the Constitutional Court's decision is the result of an interpretation of the 1945 Constitution which means that here the hierarchy is in the constitution, it will be true if other decisions that conflict with the Constitutional Court's decision (the 1945 Constitution) are ruled out. That is, the KPU implements provisions in the Constitution as a result of implementing the Constitutional Court's decision. This has a follow-up function or consequence of follow-up (hierarchical theory). When other legal products, for example, decisions interpret higher norms, the legal prefix produced under these rules should not conflict with the decision of a higher 
interpretation. So here there is a coherent nature of behavior and usability including the follow-up power contained in a norm.

\section{REFERENCES}

Asshiddiqie. Jimly. 2007. Pokok-pokok Hukum Tata Negara Indonesia Pasca Reformasi. Jakarta: Bhuana Ilmu Populer.

Budiardjo, Miriam. 2013. Dasar-Dasar Ilmu Politik. Edisi Revisi. Jakarta: Gramedia Pustaka Utama.

Harr, J. Scott and Karen M. Hess. 2002. Constitutional Law and The Criminal Justice System. Second Edition. Wadsworth: Thomson Learning.

Hoesein, Zainal Arifn. 2009. Judicial Review di Mahkamah Agung: Tiga Dekade Pengujian Peraturan Perundang-undangan. Jakarta: Raja Grafindo Persada.

Marzuki, M Laica. 2007. Membangun Undang-Undang yang Ideal, Jurnal Legislasi Indonesia. Vol. 4, No. 2. Juni. Jakarta: Direktorat Jenderal Peraturan Perundang-Undangan Departemen Hukum dan HAM RI.

Palguna, I Dewa Gege. 2013. Pengaduan Konstitusional (Constitutional Complaint), Upaya Hukum terhadap Pelanggaran Hak-Hak Konstitusional Warga Negara. Jakarta: Sinar Grafika.

Palguna, I.Dewa Gede. 2018. Mahkamah Konstitusi Dasar Pemikiran, Kewenangan, dan Perbandingan Dasar Negara Lain. Jakarta: Konstitusi Press.

Stong, CF 1966. Modern Political Constitutions, London: Sidgwick and Jackson Limited.

Sulaiman, King Faisal. 2017. Teori Peraturan Perundang-undangan dan Aspek Pengujiannya. Yogyakarta: Thafa Media.

Termorshuizen, Marjanne. 1998. Kamus hukum Belanda-Indonesia. Penerbit Djambatan.

Thaib, Dahlan, dkk. 201l. Teori dan Hukum Konstitusi. Jakarta: Raja Grafindo Persada.

Wheare, KC 1996. Modern Constitution, Second Edition. Oxford. 
320 | The Existence of Decision Norms of the Constitutional Court as a Source of Legislative and Executive Laws

This page is intentionally left blank 